IRA-International Journal of Education \&

Multidisciplinary Studies

ISSN 2455-2526; Vol.17, Issue 02 (Q2, 2021)

Pg. no. 76-79.

IRA Academico Research

\title{
An Analysis of the Connotation of Hills Like White Elephants by Hemingway from the Perspective of Stylistic Features
}

Dong Jiawei (i)

School of Literature, Xi'an Technological University, Xi'an, 710021 PRC China.

Type of Work: Peer Reviewed.

DOI: $10.21013 /$ jems.v17.n2.p5

DOI URL: https://dx.doi.org/10.21013/jems.v17.n2.p5

\begin{abstract}
How to cite this paper:
Jiawei, D. (2021). An Analysis of the Connotation of Hills Like White Elephants by Hemingway from the Perspective of Stylistic Features. IRA-International Journal of Education \& Multidisciplinary Studies (ISSN 2455-2526), 17(2), 76-79. DOI: https://dx.doi.org/10.21013/jems.v17.n2.p5
\end{abstract}

(C) IRA Academico Research.

(oc) EY-NG This work is licensed under a Creative Commons Attribution-NonCommercial 4.0 International License subject to a proper citation to the publication source of the work.

Disclaimer: The scholarly papers as reviewed and published by IRA Academico Research are the views and opinions of their respective authors and are not the views or opinions of IRA Academico Research. IRA Academico Research disclaims any harm or loss caused due to the published content to any party.

IRA Academico Research is an institutional publisher member of Publishers International Linking Association Inc. (PILA-CrossRef), USA. IRA Academico Research is an institutional signatory to the Budapest Open Access Initiative. Hungary advocating the open access of scientific and scholarly knowledge. IRA Academico Research is a registered content provider under Open Access Initiative Protocol for Metadata Harvesting (OAI-PMH).

The journal is indexed \& included in WorldCat Discovery Service (USA), CrossRef Metadata Search (USA), WorldCat (USA), OCLC (USA), Open J-Gate (India), EZB (Germany) Scilit (Switzerland), Airiti (China), Bielefeld Academic Search Engine (BASE) of Bielefeld University, Germany, PKP Index of Simon Fraser University, Canada. 


\section{ABSTRACT}

Taking the novel Hills Like White Elephants written by Hemingway as the study object, the thesis analyzes the connotation of the novel from the perspective of stylistic features. The writer adopted simple narrative technique, concise language and abundant metaphors in this short story to not only convey the incompatible contradiction between the American man and the girl but also deepen the tragic theme of the lost generation represented by the two characters.

Keywords: stylistic features; Hills Like White Elephants; novel connotation

\section{Introduction}

Hemingway's works have always been characterized of the principle "less is more". What readers usually can see is the one-eighth part of the iceberg, namely, the text, which is the medium of the exchange between the writer and readers; the seven-eighths of an underwater iceberg can be deeply interpreted by readers [1]. In terms of the literary style of Hills Like White Elephants [2], simple narrative techniques, concise language and abundant metaphors are adopted in this short story, so as to not only convey the incompatible contradiction between the American man and the girl but also deepen the tragic theme of the lost generation represented by the two characters. Therefore, the unlimited connotation can be expressed under limited forms.

\section{Simple Narrative Techniques}

First and foremost, the narrative style in Hills Like White Elephants is quite simple without any redundant techniques. Not only detailed information about characters appearance but also the description of their psychological changes are often omitted. The time, character relationship and background introduction cannot be found. The only information is just that there are two persons waiting for the express from Barcelona. One is an American man and the other is a girl named Jig. Their appearance and relationship are hidden. Readers do not even know if they are a couple or husband and wife, or if they are in an illicit relationship. The reason why the hero persuaded the heroine to have an abortion is also unknown. Also, the psychological changes of characters are all omitted. Without any words to describe, the girl's depressed mood just reflected by a few strokes of action description. She went from hopeful to disillusion and shaken to utterly chilled. In the end, she "smiled at him", although she was in the smile, it is in a wry smile and a forced smile. The man was so negative about their future that the girl was completely disappointed. The plot seems incomplete, but omitting the subplot actually enhances the performance of the main plot [3]. At the same time, readers can guess the inner thoughts of the characters, which help to enhance the interaction with readers.

\section{Concise Language}

Furthermore, language in Hills Like White Elephants is very concise both in sentence building and word choice. In terms of sentence pattern, the sentence structure is dominated by short declarative sentences rather than long and difficult sentences. Even if there are a few sentences with compound sentences, the subsidiary clauses in the main sentence are short and clear [4]. In general, indirect speech such as "he said" and "she said" is hard to find in Hills Like White Elephants, because all 144 lines of dialogue are in the form of direct speech without exception, which is so concise and straightforward that the logical relationship can be simple and easy to understand and readers can appreciate the charm of the language hierarchically. Their dialogue consists of most short declarative sentences in the form of direct speech so that their conflict on the new life can be straightforwardly focused on. Literally, he preferred the basic and common words with specific meaning and few syllables. Nouns are often used rather than adjectives, verbs rather than adverbs. For example, "She put the felt pads and the beer glasses on the table and looked at the man and the girl. The girl was looking off at the line 
of the hills." In the above sentence, there are 3 verbs "put" looked" and "are looking", but none of them is modified by any adverbs. The use of nouns and verbs are easy to directly touch on the true nature of things, making the basic feature of things clear to the reader, instead of embellishing the words to impress the audience. They mainly argued about abortion which may cause their relationship to break up. However, there is no word about this seemingly unspeakable noun-abortion. Instead, the word "it" appears 29 times in their dialogue. Its frequent appearance seemingly reflects their communication, but in fact, it can hardly touch the essence of the problem but promote their suffering and helpless mood.

\section{Abundant Metaphors}

Most significantly, in addition to simple narration and concise language, abundant metaphors play an important role in developing the meaning in Hills Like White Elephants by Hemingway. Abundant implicit meaning can be conveyed by the words "white", "white elephants" and "hill" and so on. From the scene description at the beginning, the world is obviously divided into two parts: the hill was "white in the sun" while "the county was brown and dry". In the view of girls, "white" represents elegance, purity and life, with sacred power. It hints at their main conflict, life and death, and at their attitude towards the unborn child. In the traditional concept, "white elephants" implies large and useless things [5]. But in the girl's eyes, "white elephant", as mellow as her abdomen and as pure as their unborn baby, is a fresh, lovely and new life, while in the man's eyes, it is an unaffordable burden. The girl is full of passion for life and love, while the man believes that the whole world is not theirs anymore. They are both lost in the frustrating era. In addition, Hemingway used the huge round body of the "white elephant" to symbolize the pregnant girl, which implies that the pregnant girl may become a burden in the eyes of American men. Meanwhile, the endless hills are as inscrutable and erratic as the relationship between the man and the girl, exposing the gloomy and hopeless atmosphere of American society at that time.

\section{Conclusion}

To sum up, less is more. Just like many works by Hemingway, the unlimited connotation can be expressed concisely in the short novel Hills Like White Elephants. Hemingway's writing is characterized by iceberg theory. What readers see in the novel Hills Like White Elephants with concise words and imagery just shows "the one-eighth part of the iceberg above the sea" [6]. The sad and touching story of the two characters can give rise to much thought and speculation from readers. Meanwhile, the text acts as the medium of the exchange between the writer and readers, through which readers' imagination can be triggered to explore and supplement the rest of the connotation. The limitless meaning can be held under the limited text. Admittedly, "the seven-eighths of an underwater iceberg" may vary from person to person because of their different experience. This is the saying that there is an end to the words, but not to their connotation.

\section{References}

[1]. Ehrenburg Ilya. The World Weighs a Writer's Influence.[J]. Saturday Review.1961:20

[2]. Hemingway Ernest. Men without Women. [M]. London: Penguin Books.1995:29-32

[3]. Wang Zuoliang \& Ding Wangdao. Introduction to English Stylistic [M].Beijing: Foreign Language Teaching and Research Press, 2015

[4]. Stephen C. Levinson. Pragmatics [M].Beijing \&London: Foreign Language Teaching and Research Press \& Cambridge University Press, 2001

[5]. Stubbs, M. Discourse Analysis[M]. Oxford: Blackwell,1983 
IRA-International Journal of Education \& Multidisciplinary Studies

[6]. Smith, Paul. Introduction: Hemingway and the Practical Reader[J].New Essays on Hemingway's Short Fiction, Cambridge University Press, 1998 